\title{
Sanomisen vaikeus ja välttämättömyys
}

Humanistinen tutkimus ja erityisesti kirjallisuudentutkimus ovat aitiopaikalla, kun tarkastellaan muutoksia ihmisten tavoissa hahmottaa suhdettaan ympäristöön, yhteiskuntaan ja ylipäätään siihen mitä milloinkin kutsutaan "maailmaksi". Tällä hetkellä ilmastonmuutos, ympäristökatastrofit, tekoälyn kehittyminen ja tietoisuus internetin vaaroista ja mahdollisuuksista ovat saaneet meidät etsimään vaihtoehtoja ihmiskeskeisille maailmanhahmottamisen tavoille ja etsimään reittejä ymmärtää toisenlaista, ei inhimillistä subjektiutta. Samalla kirjallisuus ja kirjallisuudentutkimus mahdollistavat nyt dramaattisina näyttäytyvien muutosten suhteellistamisen ja niiden taustalla olevien historiallisten jatkumoiden tunnistamisen.

Edellä kuvatut teemat olivat näkyvästi esillä Kirjallisuudentutkijain seuran vuosiseminaarissa "Muutos. Kirjallisuuden ja kirjallisuudentutkimuksen paikat kulttuurisessa muutoksessa" toukokuussa Joensuussa. Keskustelu niistä jatkuu Avaimen numerossa 2/2018, jossa käsitellään kaunokirjallisuuden keinoja kuvata vaikeasti sanoitettavia kokemuksia ja vaihtoehtoisia maailmoja. Kuinka löytää ilmaisukeinot traumakokemuksille? Kuinka kohdata toiseus läheisessä ihmisessä? Miten ilmaista sellaista sosiaalista epätasa-arvoa, jota kuolemakaan ei tasoita? Kuinka luoda kielessä maailmoja? Lehden kirjoituksissa pohditaan myös vaihtoehtoja representaatiokeskeisille lukemisen tavoille. Nämä kysymykset nousevat keskenään hyvin erilaisista kirjallisuuden ilmiöistä.

Anna Vuorinne tarkastelee artikkelissaan "Voiko katse raiskata?" itävaltalaisen feministisen sarjakuvataiteilijan omaelämäkerrallista sarjakuvateosta Tänään on loppuelämäsi viimeinen päivä. Vuonna 2009 ilmestynyt sarjakuva on edelleen ajankohtainen kuvatessaan kriittisesti seksuaalisen ahdistelun jokapäiväisyyttä. Vuorinne tarkastelee millaisin visuaalisin ja kielellisin keinoin sarjakuva taidemuotona pystyy kuvaamaan niin ahdistelun ja raiskauksen tuottamia traumaattisia kokemuksia kuin feministisen tietoisuuden voimistumistakin.

Elli Lehikoisen artikkelissa "Se ei olekaan pieni ihminen, vaan pieni eläin" aiheena ovat kaunokirjallisuuden vertaukset ja metaforat, joissa pienet lapset rinnastetaan eläimiin. Lehikoinen kokeilee näihin ilmauksiin sekä representatiivisen että siitä irtautuvan, posthumanismista ponnistavan tulkinnan strategioita. Hänen tulkintansa mukaan ihmiseen viittaavat eläintä tarkoittavat ilmaukset irtautuvat sekä konkreettisista vauvoista että eläimistä. Ne saavat merkityksen ihmisyyden ja eläimyyden kategorioiden huojunnan osoittajina. 


\section{Avaimen numerossa 2/2018 käsitellään \\ kaunokirjallisuuden keinoja kuvata vaikeasti \\ sanoitettavia kokemuksia ja vaihtoehtoisia maailmoita.}

Silja Vuorikuru nostaa artikkelissaan "Meren yli, näkyväksi" huomionsa kohteeksi Aino Kallaksen lyhyen novellin "Meillä on kuollut mukana". Hän tarkastelee sitä aikanaan etenkin Virossa suositun miniatyyrin lajin muodostamaa taustaa vasten ja jäljittää samalla Kallaksen tuotannon yhteyksiä virolaisen kirjallisuuden tyylivirtauksiin. Yhtä tärkeäksi teemaksi nousevat Kallaksen novellin hienovaraiset keinot kuvata saarenmaalaisen kyläyhteisön sisäisiä luokkajakoja ja kysymyksiä ihmisarvosta.

Elli-Mari Aholan huomio suuntautuu artikkelissa "Kertoja ja sisäistekijä maailmanrakentajina Jari Tammen Kalevala-muunnelmaromaanissa Kalevan solki" fiktiivisten maailmoiden rakentamisen problematiikkaan. Hän kehittelee kategorioita, joiden avulla on mahdollista tunnistaa kertomuksen sisältä erilaisia maailmanrakentamiseen osallistuvia toimijoita ja toiminnan tasoja narratologisen tutkimuksen keinoin.

Avaimeen 2/2018 sisältyy myös Kirjallisuudentutkijain seuran vuosiseminaarin kirjailijavieraan Jaakko Yli-Juonikkaan haastattelu. Yli-Juonikas ja kirjallisuudentutkija Laura Piippo pureutuvat keskustelussaan nykyromaaniin ja erilaisten uusien ja vanhojen tekstuaalisten mediumien suhteisiin.

Projektit-juttusarjassa on vuorossa Oulun yliopiston Tove Jansson Companion -hanke, jossa tutkitaan kirjailija-taiteilija Janssonin monipuolista tuotantoamuotoon, motiiveihinjatematiikkaankytkeytyvintarkennuksin. Hankkeessa syvennytään myös esitystapojen erityisyyttä käsitteleviin kysymyksiin. 
Arvosteltavina on kolme teosta: Hanna Samolan arvioitavana on Sanna Nyqvistin ja Outi Ojan Kirjalliset väärennökset. Huijauksia, plagiaatteija ja luovia lainauksia (2018). Kaisa Kurikka arvioi Ridvan Askinin teoksen Narrativeand Becoming (2016). Samuli Hägg arvioi puolestaan Laura Karttusen väitöskirjan The Hypothetical in Literature: Emotion and Emplotment (2015).

Elina Arminen ja Anna Logrén 